\title{
THE TEXTUAL STRATEGY OF EPHREM THE SYRIAN'S HYMN CONTRA HAERESES I
}

\author{
Phil J Botha \\ (University of Pretoria)
}

\begin{abstract}
The first hymn in Ephrem the Syrian's cycle Contra Haereses is translated and analysed in terms of its rhetorical and argumentative features. It seems that Ephrem used various rhetorical strategies to construct a polarity between a jealous Satan and a loving God. He argues that the heresies that became known under the names of Marcion, Bardaisan, and Mani are merely different manifestations of Satan's jealous attempt to hurt mankind. He urges the orthodox faithful to flee from this threat by illustrating how great the danger is with the help of analogies from everyday life and biblical stories.
\end{abstract}

\section{Introduction}

Ephrem the Syrian's collection of hymns known by the name Contra Haereses has drawn more attention from theologians than perhaps any of the other cycles collected under his name. The reason for this is the information it contains on the teachings of dissidents from mainstream Christianity such as Marcion, Bardaisan, and Mani. ${ }^{1}$ The purging of the documents of such movements left a void in our understanding of what they taught, so that the anti-heretical polemics became an important (although very unsatisfactory) source for knowing what they believed. ${ }^{2}$ The focus of this article, however, is not on the doctrines of these 'heretics', but on Ephrem's technique of countering their beliefs and their influence.

What techniques did Ephrem use? He, realised, to begin with, that liturgical hymns would be more effective than prose refutations, although he made use of that medium also. ${ }^{4}$ Hymns, especially those composed by a gifted and much beloved poet such as Ephrem was, would be repeated often or at least sung or heard each year at the same time. They would therefore be absorbed by the minds of the orthodox. ${ }^{5}$ The parallels, antitheses, metaphors, and word play that form the building blocks of his poetry (and his theology) could also become powerful instruments with which the teachings of heretics could be ridiculed, stereotyped, explained or exposed.

From a superficial reading of the first hymn in this cycle, it would seem that parallelism and antithesis, both used to construct polar thought 
patterns; the drawing of parallels between the three major heretic movements; comparisons with nature and illustrations from scripture; and the exposing of Satan as the source of all heresy should be included in a discussion of the textual strategy used in this hymn. With a view to the discussing of these features, the hymn will first be translated and its contents summarised in schematic form. This will then be followed by a systematic discussion of the above-mentioned and other similar features of the hymn.

\section{Translation of the hymn}

\section{Contra Haereses I}

On the melody: The judgement of the tribes. ${ }^{6}$

1. Error (false worship) among the apostate * is a source of injuries. - And love would like to be $*$ a healer with harsh medicines. - He causes pain without anger $*$ and suffering without rage. ${ }^{*}$ For there is no surgeon who would cut in hatred. - However, although his love is pleasant, his instrument is dreadful and grievous. - He is pleasant in his remedies, ${ }^{*}$ but bitter in his medicines. ${ }^{7}$

Response: Praised is he who has exposed the treachery of the Left. ${ }^{8}$

2. The Jealous One $e^{9}$ raged greatly * and injured humanity. - His bitterness (poison) incited him * and he wounded ${ }^{10}$ all whom he encountered. - With rage in his heart, * a curse in his mouth, - his source and his root are from bitterness (or: are poison). - He blooms and deceives you. ${ }^{*}$ The fruit which he holds out to you - originates from Sodom, ${ }^{11} *$ an offspring of his reasoning.

3. About the profit of $\operatorname{loss}^{12} *$ he is at all times concerned. - His disputation ${ }^{13}$ is boastful display, $*$ blurred by strife. - His snare is laid and adorned, $*$ and it seems to be a place of refuge. - His reasoning is a cloud, * a dark one ${ }^{14}$ - because it rains down death * from a clear and cloudless sky. - His storehouse is full of hail, * which he is forging continuously.

4. On the inside he is deceitful and dark, * on the outside cheerful and lovable. - Seeming cheerful, he deceives you, ${ }^{*}$ seeming peaceful, he lays you low. - He seems to be completely on your side * while he is completely against you. - He is a weaver (contriver) of all weaver bars 
(yokes, servitudes) * at all times. - While laughing, he deceives you,* while kissing, he bites you, - while (tasting) sweet, he chokes you. * Thus he treats you from beginning to end.

5. A lion, how often $*$ does it not remain calm in the open country, - or a snake, within a house * may stay without hurting anyone. - (But) the Jealous One, on the outside and on the inside * it does evil without stopping. - Even the tower of meat (an elephant) * in the east - willingly lowers its height * to a human: - the means of transport is filled with peace $*$ and the rider is filled with pride.

6. A snake, if you see one, $*$ do not be too terrified! - And a demon, when one encounters you, * despise it but don't go away! - But the Jealous One, if he should encounter you, * then seal yourself (with the sign of the cross) $)^{15}$ and flee! - Envy, if this settles on you, * then do not linger there! Go out, go away, read in (the book of) Job! * See yourself in his suffering! - For he (the Jealous One) is exhaling death; * he inhales and destroys you.

7. If a woman loves/desires you, - then your lot is that of Joseph. - And if a woman hates you, - then your burden (or journey) is that of Elijah. ${ }^{16}-$ But if your brother looks at you with the evil eye (envies you), * then obtain the wings of Jacob. ${ }^{17}$ - Abel has offered you a taste. ${ }^{18}$ - But if you want to explore Envy (the Envious One) completely, - look upon our Lord and comprehend $*$ how he was crucified innocently! ${ }^{19}$

8. It was not Envy, namely, * whose sword was drawn - and who wanted to quench with blood * the thirst of his reasoning, - (but) the surgeon had opened and taken out * the instrument of healing; - for it is Love that had cut (causing) pains * for a cure. - For whether they were cured or not, * they were proven guilty in that they treated him unjustly. - The healthy ones, however, make him glad * for having been preserved by his warnings.

9. How envious indeed was the Evil One * on the body of Bardaisan: through his (own) mouth, he cut off his hope, ${ }^{*}$ he reviled his (one) half. ${ }^{20}-$ $\mathrm{He}$ (Bardaisan) unsheathed his tongue ${ }^{21} *$ and renounced his resurrection. ${ }^{22}$ - Marcion, in turn, he (the Evil One) made raging * and insane, - and he attacked his maker * and insulted his creator. - In Mani, as if in a garment of his $(b m \bar{a} n e h) *$ he clothed himself and spoke through him.

10. He gave Bardaisan * a barn full of tares (weeds). - He suppressed and 
suffocated the grains of wheat $*$ with his thorns and weeds. - In the sheaf he bound him in $*$ together with the weeds. ${ }^{23}-$ Wolves (as) apostles he gave * to Marcion. - The sheep's clothing he stole, * to conceal them on the outside. - Through Mani, as through a pig, ${ }^{*}$ he stirs up his filth continuously. ${ }^{24}$

11. The (style of) speaking of Bardaisan $*$ was rational ${ }^{25}$ in public, - but under cover it raged on * in blasphemous secrets. - He is (like) a seduced woman, * who commits adultery in an inner (secret) room. - Marcion is a whore, * who acted shamelessly. - Mani, who so earnestly licked up * the vomit $^{26}$ of the dragon, - belched up bitterness for his sons $*$ and wormwood for his disciples.

12. With long outer garments and beryl gems * he adorned Bardaisan. - He clothed Marcion in sackcloth, * to darken the children of light. - He dyed him a pale yellowish colour, ${ }^{27} *$ Mani, to lead astray through him. - So he armed with every kind of evilness * all of them: - Marcion with blasphemy; * with deception Bardaisan; - the dregs that was left in abundance, ${ }^{*}$ he emptied into Mani. ${ }^{28}$

13. And they began, the children of the snake, * to slither about in the world, - to lead simplicity astray * and to lead innocence ${ }^{29}$ into captivity. They resemble the head of their family, * the primeval snake ${ }^{30}$ (lhwyh). He saw Eve $(l h w h)$ in Eden, * the simple-minded one. - He soothed her and she trusted; * he promised her and she was cheerful ('tpșht), - he surprised her ( $s p h h)$ and she regretted; * and he wounded her (bit her) and she mourned.

14. The (involuntary) movement of the limbs, ${ }^{31} *$ the divination of seasons, - the writings, the book of the thunder, ${ }^{*}$ another, the book of secrets, ${ }^{32}-$ the book of the troop (of demons) ${ }^{33} \ldots-*$ over against / according to the signs of the Zodiac. ${ }^{34}$ - And instead of the study * of the church, - a sheep that ruminates $*$ on the books of the saints, - these people busy themselves * with the books of loss.

15. The one whose body was healthy, ${ }^{*}$ his mind they made sick. - And he who was ill, they healed $*$ so that, when healed, he would die (spiritually). - The one (whose leg was) broken, they bandaged up * so that he would run into their snares. - In their charming of a simple-minded person, * someone stung, - the scorpion had wounded merely on the outside, * the charming wounded on the inside; - between the two deaths * the fool had 
cast himself.

16. Jezebel overcame Ahab. * His signet ring (sealed) for his (own) condemnation - the letter. ${ }^{35} *$ (Similarly) false worship caused Bardaisan to pronounce with his own tongue * the charge against him. $-\mathrm{He}$ also set his hand, * Marcion, - to the record of his debts. * Mani in his Madrashe put down in writing that he had, to his companion, ${ }^{36} *$ sold his freedom.

17. In the caves of Bardaisan * there were melodies and songs. ${ }^{37}-$ Since he saw how youth * longs for sweetness, - through the harmony of his hymns * he excited youth to excess. - Marcion, since he was like a snake, ${ }^{*}$ fasted. - More and more he threw in words * of the snake into his audience. Mani made his mouth to flow $*$ with a flood of his pronouncements.

18. They suddenly destroyed the cloister $^{38} *$ of Bardaisan ; - for he did not read in it * the prophets, the sons of truth; - instead the writings on the signs of $\operatorname{Zodiac}^{39} *$ he read in it and explained in it. - Marcion, furthermore, who had renounced $*$ his creator: - creation threatened him, * (so that) he tottered and staggered around in it. - Since Mani brayed (roared, creaked) so excessively, * the children of the east flayed him. ${ }^{40}$

\section{Completed}

An overview of the structure of this hymn might look like this:

1 False worship as illness, and the methods of Love, the healing surgeon.

2-7 The injuries caused by (the) jealousy (of the evil enemy):

2-4: The effects of the Jealous One, the reasons why he rages and why he is so successful.

5-6: The Jealous One more dangerous than a lion, a snake, and a demon.

7: $\quad$ The effects of desire and hate in comparison to jealousy.

8 In contrast, the work of the surgeon.

9-12 The evil enemy equips the heretics:

- Bardaisan equipped with disregard for the body, with weeds to suffocate the wheat, with seeming rational speech, with beautiful clothes and gems, with deception.

- Marcion equipped with hate against his creator, with apostles who are wolves in sheep's clothing, with misleading sackcloth, with blasphemy. 
- Mani was used by him as a garment, he stirred up his own filth through him, and belched up bitterness through him. He dyed this garment of his pale yellowish to lead people astray; he emptied the dregs of evilness into him.

13-17 The heretics as children of the primeval snake:

13: Eve deceived in Eden.

14: Magic and astrology.

15: Healing of the sick and divination.

16: Composition of their own books: the books of Bardaisan and Marcion, the hymns of Mani.

17: The cultic practices of heretics: the songs of Bardaisan, the speeches of Marcion, the promises of Mani.

18 Concluding stanza: The deserved end of the heretics:

- Destruction of the church of Bardaisan.

- Wanderings of Marcion.

- Mani persecuted by the Persians.

\section{The textual strategy of this hymn}

With 'textual strategy', I mean the way in which the text was constructed and structured with the purpose of making it a 'vehicle of meaningful persuasive discourse in its original historical, social, and cultural context and as a medium of social interaction'. ${ }^{41}$ The historical context is fourthcentury Syrian Christianity. At that time, conditions in the Syriac speaking Church probably did not differ fundamentally from the rest of the early Church. $^{42}$ However, the orthodox Christian community that Ephrem represented possibly formed only a small and relatively weak part of Syrian Christianity, so that it called for much courage to stand up for orthodox faith as he saw it. ${ }^{43}$ The social and cultural context is therefore one of fierce controversy, a battle to establish truth and tradition despite the fact that the founders of deviant movements such as Bardaisan, Marcion, and Mani had been dead for a hundred ${ }^{44}$ hundred and fifty, ${ }^{45}$ or two hundred ${ }^{46}$ years. The partisan strain that characterises almost all of Ephrem's metrical compositions strongly suggests that he was 'actively engaged in an open struggle to win the allegiance of peoples' minds and hearts to true Christianity'. ${ }^{47}$

As far as the social context is concerned, it must be noted that the disputations in these hymns are directed at the general Christian public. One would not expect, therefore, to find complex and in-depth discussions of the doctrines of heretics, but rather a kind of guerrilla attack on what was 
popularly known or believed about these movements. ${ }^{48}$ Aspects that presented a particular lure to Christians who had only recently been converted, would also be focused upon. ${ }^{49}$

Although it might seem that only the rhetorical devices and strategy of this hymn are investigated, the investigation is undertaken with the presupposition that intertextual aspects and the social and cultural context of this hymn cannot be ignored. Ephrem writes in response to pronouncements of leaders of the heretic movements (or in response to the popular understanding of such pronouncements). He is also continuously alluding to biblical contexts so as to invoke various scriptural voices as the final authority. Such intertextual connections are not investigated fully. It is also important to realise that the core biblical social values of honour and shame, as well as various means values used to establish honour and avoid shame, were still prevalent in the world of Ephrem and his opponents. The focus in the following section will, however, be on what Robbins has called 'inner texture' within a socio-rhetorical model of interpretation: ${ }^{50}$ its rhetorical and argumentative features.

\subsection{The use of polarities}

Ephrem was very fond of polar patterns. He would use instances of antithesis, merismus, paradox, and parallelism to create opposition between comparable but mutually exclusive entities. In this hymn, such a polarity is formed between false worship and love. False worship is the source of wounds to humanity while Love, a metaphor for God, is the surgeon who wants to remove the source of suffering by cutting it out (stanza 1). Such an operation causes pain also, but the motive is good. There exists therefore a paradox in the working of Love itself: it is pleasant, but uses dreadful and grievous instruments; its remedy is pleasant, but its medicine bitter (stanza 1). False worship is then described as the instrument used by Satan, the Jealous One, to harm humanity (stanza 2). Satan himself therefore stands in opposition to God who is represented as the loving surgeon. Satan' intention is to hurt humanity through deception. This hate against mankind is born from jealousy because of Adam/humanity's privileged position in creation.

The idea of deception creates another polarity, that between what is openly visible or revealed, and that which is hidden and concealed by Satan. Satan's source and root are bitterness, Ephrem insists, but he conceals this with blossoms and enticing fruit (stanza 2). Satan's arguing is impressive 
and might seem like a place of refuge, but in reality it is a laid snare and a dark cloud that rains down death from a clear and cloudless sky (stanza 2). What one sees on the outside is cheerfulness, lovableness, peacefulness, support, kissing, and sweet taste. What one gets, what is inside, is deception, attack, servitude, opposition, biting, and choking (stanza 4). The same polarity is also evident in stanza 9 where it is said that Satan clothed himself in Mani as if in a garment. Satan also concealed Bardaisan among the believers and disguised Marcion's apostles in sheep's clothing, while in reality they were wolves (stanza 10). Bardaisan's style of speaking, Ephrem says, was rational in the open, in public, but secretly it was full of blasphemous secrets (stanza 11). To construct this polarity, Ephrem thus makes use of various metaphors and similes. He also uses antithesis and merismus to construct the polarity between what is concealed and what is perceived.

Yet another polarity is formed when Ephrem takes up the opposition between 'outside' and 'inside' from stanza 4 and shows in stanza 5 how dangerous animals are far less threatening than Satan's jealousy. A lion outside in the open country is not necessarily dangerous to humans, neither is a snake within the house always a threat. However, the Jealous One always $^{51}$ does evil on the outside and on the inside. He is also compared with an elephant, itself a very dangerous animal, but one that can exist in harmony with its driver and thus not to be feared as much as Satan.

In stanza 6, a comparison is made between the danger posed by a snake and a demon and that by Satan. The listener is advised to make the sign of the cross when confronted by Satan, the Jealous One, to flee from him and to go and read in the book of Job. The connection between Satan and Job seems to be that Satan was envious of Job's privileged position before God and because of this almost destroyed him. ${ }^{52}$

In stanza 7 a polarity is formed between men and women and a comparison is made between the respective problems caused by a woman desiring a man, hating a man, and a man having to cope with the envy of another man. The biblical examples of Joseph, Elijah, Jacob, and Abel are used to demonstrate that neither a positive nor a negative disposition in a woman is as dangerous as the envy of a 'brother'. Jesus' death on the cross is used to demonstrate how dangerous envy can be, especially the envy of Satan.

This envy of Satan is subsequently contrasted itself again with the love of God. This happens in stanza 8 when Ephrem teaches that it was not Satan's 
envy that killed Christ, but the love of God that used his death as a cure for all humanity. This does not imply, Ephrem points out, that those who crucified him are innocent.

The contrast between body and spirit is used as a polarity in stanza 15 . Ephrem describes how the heretics would heal simple-minded people's bodies, so as to make them spiritually sick: a broken leg would be bandaged, so that the victim could run into the snares laid for him; someone stung on the outside by a scorpion would be charmed so that the charming would wound that person on the inside.

It would seem that Ephrem used polarities in his arguments (inter alia) because a polarity helps to delineate and juxtapose opposite elements of any subject. Constructing polarities is a powerful argumentative technique, because it leaves no grey areas. The choice the audience has to make is obvious, because the pros and cons are spelled out in detail. The objective in this case seems to be primarily to inform the audience of doctrinal dangers, to reveal to them that Satan is the unifying evil force with cruel intentions behind the diverse heretic movements, and to warn them against interest in and sympathy for these movements because it would mean to choose against God. The polemic character and the ideology of the hymn are evident in the second person forms used in the hymn:

'The fruit which he holds out to you...' (stanza 2); 'Seeming cheerful, he deceives you, seeming peaceful, he lays you low. He seems to be completely on your side while he is completely against you'; 'while laughing, he deceives you, while kissing, he bites you, while tasting sweet, he chokes you' (stanza 4).

In stanzas 6 and 7, this mode of speech is brought to a climax with direct imperatives to emphasise the danger of Satan's onslaught: 'But the Jealous One, if he should encounter you, then seal yourself with the sign of the cross and flee! ... Do not linger there! Go out, go away, and read in Job! See yourself in his suffering!', 'obtain the wings of Jacob!'

It might seem that Ephrem is jumping from topic to topic, following the possibilities that word play offer and exploring superficial similarities between the heresies. ${ }^{53}$ But this is not the case. As the summary of the contents above has shown, his hymn is a carefully constructed argument, departing from the premise that all heresies can be traced to the jealousy, hate, bitterness, and evil intentions of Satan. He investigates the origin of 
the three major heresies at the beginning of the hymn and effects closure of the hymn by describing the punishment of their founders in the last stanza. ${ }^{54} \mathrm{He}$ argues by constructing polarities from numerous antithetic parallels and by urging his audience to dissociate from those poles characterised by words with a negative connotation and to embrace the positive alternatives in each case.

\subsection{Illustrations from nature and from scripture}

Ephrem considered nature and everyday activities of people as a source of illustrations to drive certain points home. In a similar way, the experience of characters from the Bible could serve as authoritative haggadic examples of the truths he was explaining. In this hymn the audience hears about the surgeon with his dreadful and grievous knife, a dark cloud raining down death and continually producing hail, a weaver who produces yokes of servitude, dangerous animals such as a lion, a snake, and an elephant, what one should do in case of an encounter with a demon, the disgraceful conduct of a whore, the charming of people who were bitten by snakes and stung by scorpions, and about Bardaisan who soothed the young people of his day with beautiful songs. These were certainly the elements that made a hymn like this one interesting and memorable. The fact that these images were known to almost everybody made them powerful argumentative aids that gave a sense of reality and urgency to the warnings he issued.

The same applies to the use of stories from the Bible and intertextual allusions to well-known parts of scripture. Such illustrations would explain the biblical text, providing implicit exegesis, while it gave an authoritative ring to the arguments. The stories about Eve, Jacob, Joseph, Elijah, Naboth, and Job all helped to emphasise the danger lurking beneath the surface of the heretical movements. The parable of the wheat and tares, the image of wolves in sheep's clothing, and the image of a pig stirring up filth, taken from 2 Peter 2:22, all contributed to the hymn's effectiveness.

While these allusions helped to convince the audience that the arguments about the danger of these movements that were put forward, were true, they also served to spread the conviction that these heresies were already condemned by God. Nobody would argue, for example, that Jezebel and Ahab were condemned by God. They could therefore conveniently be used as anti-types and symbols of the condemnation of Bardaisan, Marcion, and Mani (cf. stanza 16). 
Ephrem would not hesitate to use negative connotation to discourage members of the orthodox community from associating with heretics. The common human phobia of snakes is put to good use. After assuring his audience that a real snake is not as dangerous as the jealousy of Satan (stanzas 5 and 6), he refers to Satan as the primeval snake and the heretics as the children of the snake (stanza 13). Marcion's habit of fasting is ascribed to the fact that he 'was like a snake' (stanza 17), ${ }^{55}$ and it comes as no surprise, therefore, when we hear that he threw in 'words of the snake into his audience' more and more (stanza 17). The same technique of negative association is also used in stanza 11. In it, Bardaisan is described as 'a seduced woman, who commits adultery in an inner (secret) room', Marcion is said to be 'a whore who acted shamelessly' and Mani is described as eagerly licking up 'the vomit of the dragon' so as to 'belch up bitterness and wormwood'. Some of these words have an extremely negative connotation and could seem strange in a liturgical setting. Compare in this regard also the 'hog/wild boar' continually 'stirring up $\mathrm{mud} / \mathrm{mire} /$ filth' used in a comparison with Mani in stanza 10, although this is an image already used in the biblical book of 2 Peter.

\subsection{The drawing of parallels between the heretic movements and the exposing of Satan as the common source of all heretic ideas}

A last important feature of this hymn is the parallels that Ephrem draws between the three important heretic movements. By showing that the three movements display similar characteristics, he is able to infer that they have a common origin. The Evil One, the source of all evil, was using all of them to hurt humanity in various ways. We find such comparisons in stanzas 9-12 and 17-18.

The first aspect of comparison between the movements is the heretical pronouncements by their leaders. Satan is unmasked as the source of illogical and blasphemous speech in these leaders. As a result of his instigation, Bardaisan 'reviled' one half of himself (his body), since he 'renounced his resurrection' and Marcion 'attacked his creator' and 'insulted' his maker. Satan also 'spoke' through Mani after clothing himself in Mani as if in a garment of his. This last image is based on wordplay $(b m a \bar{a} n e h=$ through his garment), which suggests the close association, almost an identity, between Satan and Mani.

In stanza 10, the focus is on the equipment Satan gave to the heretical leaders. He gave Bardaisan 'a barn full of tares' to suppress and suffocate 
the believers. Ephrem also refers to Satan's 'thorns and weeds', possibly an allusion to Genesis 3:18, in order to emphasise the link between Bardaisan and Satan as the primeval snake. When Ephrem subsequently turns to Marcion, he is looking for another image from the words of Jesus to describe the influence of Marcion. He finds this in Matthew 7:15, where Jesus warns his followers to be on their guard for false prophets. Satan 'stole' sheep's clothing to give to Marcion to conceal his apostles with. Ephrem then finally turns to Mani. There is no parable that fits, it seems. However, there is a biblical image that can be applied, namely the image of a dog that returns to its vomit, and a sow that is washed that goes back to her wallowing in the mud. He uses the second half of 2 Peter 2:22 here, and the first half of the same verse to describe Mani again with in the following stanza. With all these allusions, the authority of scripture is invoked to prove that Jesus and the apostles foresaw the heretical movements and that their warnings are applicable to the circumstances of the audience. These allusions simultaneously prove that Satan, the primary enemy of God and humanity, instigated all the heretical movements.

It seems that the tertium comparationis between Bardaisan and Marcion in stanza 11 lies in the immoral quality of their actions. Bardaisan acted 'immorally' by speaking rationally in public, but making blasphemous statements privately. This gives occasion to compare him to a (married) woman who commits adultery in an inner room of a house. Marcion, according to Ephrem, went further, since he openly 'adulterated' (not his term) the doctrine of the church with philosophical ideas. He can therefore be described as a 'whore'. When it is Mani's turn, Ephrem seems to turn away from this imagery, since he describes Mani as the heretic who 'earnestly licked up the vomit of the dragon' and 'belched up bitterness for his sons and wormwood for his disciples'. Kronholm interprets this vomiting as sickness because of the defilement of Satan that Mani had consumed. ${ }^{56}$ But the eagerness with which he did this argues against such an interpretation. The connection with the biblical image also suggests that this is simply a way of saying that he conveyed the poison of Satan to his followers. The mentioning of 'sons' suggests that Ephrem is possibly still using the same point of comparison. The 'vomit of the dragon' which Mani 'earnestly licked up' should then be seen as the way in which he was also 'inseminated' by Satan to procreate evil ideas. ${ }^{57}$ It is, in any case, almost certain that Bardaisan's adultery and Marcion's harlotry should be understood as their being seduced by Satan. The offspring produced by this 'intercourse' is called 'the children of the snake' in stanza 13. They, the followers of the heretic pioneers, 'resemble the head of their family, the 
primeval snake' who wounded Eve in Eden.

Stanza 12 compares the three heretics in terms of the way in which they were adorned by Satan: Bardaisan was given 'long outer garments and beryl gems', Marcion was clothed in 'sackcloth' and Mani was given a pale yellowish colour. These adornments were supposed to help Bardaisan with his deception and Marcion with his endeavours to "darken the children of light'. The sackcloth and the dye, it seems, were signs of ascetics and the implication is that Marcion and Mani deceived people to believe that they truly lived a life of submission and humility, while this was only a ploy of Satan.

Stanza 17 takes as its theme the cultic gatherings of the three movements. Bardaisan's gatherings were characterised by singing. Marcion fasted, imitating true believers, but this was only, we are told, because Marcion was like a (hibernating?) snake. His true character, Ephrem would like to emphasise, is evident in his sermons, since he 'threw in words of the snake into his audience' more and more. The same connection with Satan is not hinted at, but it is said that Mani also made his mouth to flow with a flood of pronouncements. Finally, in stanza 18 Ephrem describes the end of the three heretic leaders. What happened to them (or to the place of worship he used in the case of Bardaisan) is related to what they did. This would seem to suggest that history has already pointed out that God has punished them: Bardaisan read the writings of the signs of Zodiac in his church instead of the prophets; therefore people ('they') destroyed it. Marcion renounced his Creator, therefore he was 'threatened' by creation, causing him to totter and stagger around in the world ironically. Mani 'roared' so excessively in his pronouncements that the children of the east 'flayed' him. The connection seems to be that he acted animal-like and thus died like an animal.

The technique used in these stanzas is that of association. By making comparisons between these religious movements, and by linking one or more of them to Satan, Ephrem argues that the heretic movements were simply different attempts of Satan to harm humanity. Satan was envious of Adam, and thus of humanity, because of the privileged status that God gave to mankind. False worship is an attempt of the Evil One to injure humanity. Through these heresies he deceives, bites, chokes, misleads, wounds, and kills humans. The source and root of Satan is bitterness, and he would use any means at all times to try to hurt anyone. Different heresies are merely different manifestations of the same old jealousy of the Evil One. God, represented as Love, is a surgeon who wants to heal these wounds and 
restore humanity to its original state of wholeness.

\section{Conclusion}

From this analysis, it is clear that this hymn is a polemical rather than a dogmatic document. Many of its features are congruent with the style and theology of Ephrem, Father of the Syrian Church. Its implied audience is orthodox Syrian Christianity of the fourth century. The author uses various literary and argumentative devices to convince the audience that vestiges of Bardaisan's theology and the heresies of Marcion and Mani still prevalent in their society are outcrops of Satan's jealousy of humanity and attempts by him to hurt humanity. With the help of parallels, antitheses, and paradoxes, he constructs polarities which would seem to press the audience to make a choice for God and thus for orthodoxy. He would argue from everyday human experience and with the help of various allusions to scripture, that Satan and the movements which he uses to entrap people are more dangerous than wild animals and even demons, and the best safeguard is to flee from them. He would want his audience to be completely convinced that the similarities between the movements prove that they are the same at heart and that God has already displayed his judgement on them by what has happened to their leaders.

The strategy of the text can therefore be described as an attempt to formulate a collective identity in three of the major heretic movements of the time as a dangerous out-group. Internal solidarity and cohesion is encouraged through illustrations and warnings to avoid the practices and meetings of these movements and by staying loyal to a loving God and to the teachings of Jesus Christ as manifested by orthodox theology.

\section{NOTES}

1 E. Beck, Des Heiligen Ephraem des Syrers Hymnen Contra Haereses, (CSCO Vol. 169 (text) and Vol. 170 (translation), Scriptores Syri Tomus 76-77), Louvain 1957, Vol. 170 p.i.

2 Cf. A. Rücker, Des Heiligen Ephräm des Syrers Hymnen gegen die Irrlehren, aus dem Syrischen übersetzt und mit einer Einleitung versehen, München, 1928, (Bibliothek der Kirchenväter), pp.xii-xiii.

3 The Syriac title of the London manuscript followed by Beck can be translated as 'Against the doctrines', since $y w l p n$ ' is used without the specification $t^{\prime} y$ '. Beck (op. cit., Vol. 170, p.i) notes that the German word 
'Irrlehren' would have given a better translation than Contra Haereses. Rücker (op. cit., p.1) translates the title of the Vatican ms as 'Hymnen gegen die Irrlehren vom seligen Mar Ephräm'.

Ephrem's polemics against Bardaisan are found in his Prose Refutations I and II (1-49 and 143-169), but seem to be concentrated in the hymns $\mathrm{CH}$ and CNis. - see T. Kronholm, Motifs from Genesis 1-11 in the genuine hymns of Ephrem the Syrian, with particular reference to the influence of Jewish exegetical tradition, Lund 1978, p.29. Kronholm (ibid., p.31) says that Ephrem's criticism of Mani and Manicheism is almost entirely confined to the collection $\mathrm{CH}$, while that against the Marcionites 'is concentrated to Contra Haereses, with a few exceptions'. Ibid., p.32.

5 Bardaisan created the Gattung of 'Madrášê to improve the spread of his teachings among ordinary people. 'Ephräm übernahm sie als Waffe für den Kampf gegen die Häresien' (Rücker, op. cit., p.xvi). A song-leader would sing the composition, with the congregation repeating the refrain after each stanza. Rücker (ibid., p.xvii) says 'Diese Art des Gesangsvortrages ist auch heute noch im Orient sehr beliebt, und wir können uns daraus eine Vorstellung machen, daß auf diese Weise leicht Ideen unter das Volk getragen werden konnten.'

6 This particular melody, used in hymns 1-10 and 52, has a metrical pattern used also in Ephrem's Hymns on Paradise. It has therefore nothing to do with the contents of the hymn.

7 There is wordplay between 'pleasant' (basîm) and 'medicine' (besmâ).

8 The 'Left' refers to Satan and his kingdom as opposed to the 'Right', which, according to the Hymns De Ecclesia 24, represents Christ and his kingdom. Cf. Beck, Vol. 170 (op. cit.), p.1 n.2. Rücker (op. cit., p.2, n.1) refers to it as the 'Seite der Verworfenheit'.

9 According to Beck, Vol. 170 (op. cit. p.2 n.3), the description of 'Jealousy' is a reference to Satan. Even when the abstract idea of jealousy is referred to in this hymn, the person of Satan (the 'Evil One') also plays a role in the description. Ephrem repeatedly in his hymns refers to Satan's envy of Adam/man on account of his universal kingship over all things and his "preeminently distinct endowment in all respects' (Kronholm, op. cit., p.90). He was also envious of Christ because he was incarnated in the humanity of Adam (HdF 50:6, cf. Kronholm, ibid., p.91). Kronholm (ibid., pp.91-92, n.19) makes the interesting remark that this motif is also found in Josephus, Rabbinic literature, early patristic literature, and even the Koran.

Rücker (op. cit., p.2) translates 'sein Gift macht ihn rasend, und er beißt, wen er nur trifft'. It is possibly a reference to Genesis 3:15.

According to Beck (op. cit., Vol. 170 p.2 n.4), Sodom represents 'unsere Äon der Sünde' in Nat. 5:6. He also refers to CNis. 40:78 where it is said that the people tended their vineyards but allowed their spirit to be a vine 
from the vines of Sodom, booty for the boar from the forest. In the present text and in CNis 40:78, Deut. 32:32 obviously served as an intertextual reference ('Their vine comes from the vine of Sodom and from the fields of Gomorrah. Their grapes are filled with poison, and their clusters with bitterness' - NIB). Ps 80:14 (Masoretic Text) also played a role in the composition of CNis 40:78: 'Boars from the forest ravage it and the creatures of the field feed on it' - NIB, Ps 80:13). For the importance of Deuteronomy 32:32 in the work of both Aphrahat and Ephrem, cf. R. Murray, Symbols of Church and Kingdom: A study in early Syriac Tradition, Cambridge 1975, pp. 96-104.

Or: 'the fullness/capital of loss'. Beck (op. cit., Vol. 170, p.2 n.5) draws our attention to $\mathrm{CH} 28: 4$ where nature is represented as capital that can lead to a loss or a profit. Satan thinks continually of the possibility that nature can be used to the disadvantage of humanity.

I follow the interpretation of Beck (op. cit., Vol. 170, p.2 n.6 = d-rāšsh) against that of Rücker who reads $d-r e \overline{s e} e h$ and translates with 'his head...'.

In this respect, Satan is the opposite of God, since Ephrem thought of sun/fire, warmth, and light as symbols of the Trinity. Cf. E. Beck, Ephräms Trinitätslehre im Bild von Sonne/Feuer, Licht und Wärme, Louvain 1981, p.115.

Cf. Beck's explanation (op. cit., Vol. 170, p.3 n.9). He refers to Virg 37:1 where prayer and making the sign of the cross are described as a weapon against Satan.

Cf. 1 Kings 19:3.

I.e., flee as Jacob did from his brother.

A taste of the misfortune that envy can cause.

As Kronholm (op. cit., p.147) remarks, Abel offered a specimen of 'those sufferings that the jealousy of a fallen humanity inflicts upon the righteous in every age, the paramount sufferer of which is the Crucified'.

Beck informs us (op. cit., Vol. 170, p.3 n.14) that this refers to the body. He notes that the same word is used in CNis 35:112 to refer to the humanity of Christ in contradistinction to his divinity.

21 This might be a play on Prov. 12:18.

According to Beck (op. cit., Vol. 170, p.5 n.29), Ephrem refers to this book of Bardaisan also in CNis 51:10. In it, he read the doctrine of Bardaisan about the body not being resurrected.

The parable in Matthew 13:24-30 is used as intertext in this stanza, and words from the context of Matthew 7:15 ('wolves' and 'sheep's clothing') are thrown in as well. In Matthew 13:30 it is the reapers/harvesters who tie the weeds in bundles to be burned. It seems that Satan is the subject of the verb ('sr) here: 'he tied him in'.

2 Peter 2:22 provides the background for this image. 
With Beck (op. cit., Vol. 170, p.4 n.18), mnkp is translated here 'rational' or 'sensible', since it is meant to form an antithesis with 'insane' in the following line. Beck points to the connection between this word and 'sensible' in the Peshitta text of Mark 5:15.

Cf. (again) 2 Peter 2:22. In view of the fact that this verse is alluded to in the previous stanza, it may be argued that its other half is now brought into play.

According to Beck (op. cit., Vol. 170, p.4 n.21), the wearing of yellow facial paint was characteristic of ascetics.

Evidently, Ephrem considered Mani to be the summit of heresy. Cf. in this regard $C H$ 22:17 and 22; 41:8; and 51:14 and Kronholm, op. cit., p.31.

'Simplicity and 'innocence' refer also to Eve who is portrayed by Ephrem as someone with no experience, having been created only a short while before the encounter with the serpent.

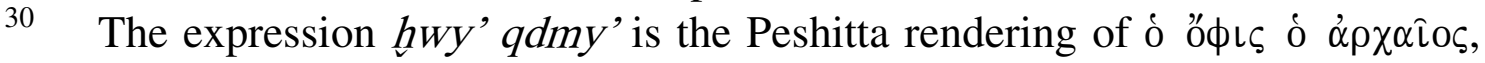
Kronholm (op. cit., p.93) informs us. But its Hebrew equivalent, נחש הקדמונים ס is frequently found in the Rabbinic literature, e.g. Sifre ad Deut. 32:32 (ibid., n.23), a text that incidentally plays an important role in the third stanza of this hymn!

J. Payne Smith (A compendious Syriac Dictionary, founded upon the Thesaurus Syriacus of R. Payne Smith, Oxford [1903] 1976, p.548) notes that observing of involuntary movements was a form of divination.

One of the books of Bardaisan. Cf. Beck (op. cit., Vol. 170), p.5 n.25.

Beck (op. cit., Vol. 170, p.5 n.26) refers to the Syriac Romance of Julian and the writings of Isaac of Antioch from which it seems evident that this description refers to a book used for exorcism in which the names of all evil spirits were written.

34 The meaning of this line is not clear. All that seems certain is that reference is made to a book on the signs of Zodiac, a writing that seems to be mentioned in stanza 18 once more.

35 Cf. 1 Kings 21:8.

36 According to Beck's notes (op. cit., Vol. 170, p.5 n.30), this refers to Satan. Cf. Virg 27:3 where mention is also made of the singing in the recesses of the heretics.

38

The word hâbuštâ ('enclosure, cloister, cell, stronghold') probably refers to the place of worship of Bardaisan's followers. Beck (op. cit., Vol. 170, p.6) translates it with 'Klause', but explains that it refers to the cultic centre of his congregation. He also notes in his translation (n.33 on p.6) that it is related in the Life of Rabbula that it was he, Rabbula, who demolished the $b \bar{e} t$ knu ̌́tâ of the Bardaisanites in Edessa. If this stanza refers to that incident, then it must be a later insertion, Beck notes. Rabbula became bishop in 411 A.D. (J.G.G. Norman, article s.v. 'Rabbula' in J.D. Douglas 
(ed.), The New International Dictionary of the Christian Church, Paternoster Press, 1974, p.820).

According to the teaching of Bardaisan, matter was divided into four pure 'elements' or 'self-existent beings'. This had astrological consequences, against which this stanza polemicizes. Cf. Kronholm, op. cit., p.29.

Rücker (op. cit., p.6 n.2) notes 'Daß Mani geschunden wurde, sagt Ephräm auch in der 2. Abhandlung an Hypatius'.

41 The quote is from J.H. Elliott, What is Social-Scientific Criticism? (Guides to Biblical Scholarship), Minneapolis 1993, p.69. It is a method of exegesis of biblical texts, but one that can be applied to any religious, and thus ideological, text.

Cf. P.S. Russel, St. Ephraem the Syrian and St. Gregory the theologian confront the Arians (Moran 'Eth'o 5), St. Ephrem Ecumenical Research Institute, Kottayam 1994, p.3.

Russel, op. cit. p.12, writes that, in terms of the Arian controversy in the Church, the Nicene element championed by Ephrem was a small and relatively weak part of Syrian Christianity.

Mani died in February of either 276 or 277 (J.N. Birdsall, article s.v. 'Manichaeism', in J.D. Douglas (op. cit., pp.624-625, p.624).

Bardaisan lived from 154-222 (C.P. Williams, article s.v. 'Bardesanes' in J.D. Douglas, op. cit., p.104).

Marcion was excommunicated c.144 (W.W. Gasque, article s.v. 'Marcion', in J.D. Douglas, op. cit., pp.629-630, p.629).

S.H. Griffith, Ephraem the Deacon of Edessa, and the Church of the Empire, in: E. Ferguson, D.M Scholer, \& P.C. Finney (eds.), Studies in Early Christianity: A collection of Scholarly Essays, Volume I: Personalities of the Early Church (edited By E. Ferguson), New York \& London 1993, pp.240-270, p.243.

48 Rücker, op. cit., pp.xxiv-xxv.

49 'Es waren zunächst Gefahren allgemeiner Natur, wie sie in Gebieten, die vor kurzem noch heidnisch waren oder sogar noch starke heidnische Enklaven aufwiesen, von selbst gegeben waren: allerlei Aberglauben, Zauberei, Beschwörungen, Beobachten gewisser Zeiten und Vorzeichen u. dgl. waren nicht auf einmal auszurotten...' Rücker, op. cit., p.xxv.

V.K. Robbins, The tapestry of Early Christian Discourse: Rhetoric, society and ideology, London and New York (Routledge), 1996, pp.18-43.

51 I have written an article on Ephrem's theological use of the particle $k l$ (P.J Botha, The Theology of Totality: Ephrem the Syrian's Use of the Particle $\mathrm{u}$ (all), in E.A. Livingstone, Studia Patristica Vol. XXV (Papers presented at the Eleventh International Conference on Patristic Studies, Oxford 1991), Leuven 1993, pp.223-228). It seems that it could also be used anti- 
theologically, since it is used in this hymn to describe the encompassing attack of Satan on humanity through the heretics. Cf. stanzas 2, 4, and 12. Cf. Job 1:9-11.

53 Rücker (op. cit., p.xiii) writes: 'Es ist nicht Ephräms Art, systematisch und Schritt für Schritt seine Gedanken zu entwickeln; Äußerlichkeiten, Wortspiele u. a. veranlassen ihn oft, seine Gedankenfolge zu unterbrechen und vielleicht erst einer Nebensächlichkeit nachzugehen, die ihn reizte.'

This implies that the final stanza was written by Ephrem, and that the destruction of the place of worship of Bardaisan referred to in that stanza cannot refer to the purging by Rabbula.

55 Ephrem probably thought of a hibernating snake in this regard.

56 Kronholm, op. cit., p.32.

57 Note the idea, sufficiently represented in the works of Ephrem, that the serpent sexually seduced Eve by ejecting venom into her ears (Kronholm, op. cit., p.101). Eve was thus turned into a vessel or instrument of the venom of the serpent (Kronholm, op. cit., p.102). 